\title{
Failure of Iron Chelators to Protect Against Cerebral Infarction in Hypoxia-Ischemia
}

\author{
V. MacMillan, I. Fridovich and J. Davis
}

\begin{abstract}
In this study the ability of iron chelators to attenuate hypoxic-ischemic brain damage was assessed in hyperglycemic rats that were exposed to $1 \%$ carbon monoxide and right carotid occlusion. The animals received deferoxamine $(50 \mathrm{mg} / \mathrm{kg})$, manganese-deferoxamine $(50 \mathrm{mg} / \mathrm{kg}$ ) or vehicle i.p. $0.5 \mathrm{~h}$ prior to hypoxemic-ischemic exposure and at $0.5,3$ and $24 \mathrm{~h}$ post-exposure; with subsequent histological examination of the brain at 7 days recovery. The area of cerebral infarction was measured at three levels using video imaging methods. The mean percentage of total hemisphere that was infarcted in the three groups was: vehicle $-28.5 \pm 5.0$; deferoxamine $-31.7 \pm 12.1$; and manganese deferoxamine $-30.6 \pm 6.8(\mathrm{p}-\mathrm{n}$.s.). The results as obtained in this preliminary study indicate that aggressive pre- and post-treatment with iron chelators has no ability to attenuate cerebral infarction in this model.
\end{abstract}

RÉSUMÉ: Les chélateurs du fer ne protègent pas de l'infarctus cérébral dans l'hypoxie-ischémie. Nous avons évalué la capacité des chélateurs du fer d'atténuer les dommages hypoxiques-ischémiques au niveau de cerveau de rats hyperglycémiques qui étaient exposés à de l'oxyde de carbone et à une occlusion de la carotide droite. Les animaux ont reçu de la déféroxamine $(50 \mathrm{mg} / \mathrm{kg})$, du manganèse-déféroxamine $(50 \mathrm{mg} / \mathrm{kg})$ ou le véhicule i.p. $0.5 \mathrm{~h}$. avant l'exposition à l'hypoxie-ischémie et à $0.5,3$ et $24 \mathrm{~h}$. post-exposition. On a procédé à un examen histologique du cerveau au septième jour de la péroide de récupération. La zone cérébrale infarcisée a été mesurée à trois niveaux par des méthodes d'imagerie vidéo. Le pourcentage moyen hémisphérique infarcisé était de $28.5 \pm 5.0$ pour le véhicule, $31.7 \pm 12.1$ pour la déféroxamine et de $30.6 \pm 6.8$ pour le manganèse-déféroxamine $(\mathrm{p}-\mathrm{n} . \mathrm{s}$.). Ces résultats préléminaires indiquent qu'un pré- ou post-traitement agressif avec un chélateur du fer ne peut pas atténuer l'infarctus cérébral dans ce modèle expérimental.

Can. J. Neurol. Sci. 1993: 20:41-43

It has been suggested that anoxic-ischemic brain damage is in part due to lipid peroxidation which is induced or catalyzed by iron released from cellular storage 'sites. ${ }^{1.2}$ In this hypothesis it is proposed that severe tissue lactic acidosis causes a delocation of ferric iron $\left(\mathrm{Fe}^{3+}\right)$ from transferrin and ferritin with subsequent catalytic reactions with superoxide anions $\left(.0_{2}-\right)$ and hydrogen peroxide $\left(\mathrm{H}_{2} \mathrm{O}_{2}\right)$ to yield the tissue damaging hydroxyl (.OH-) radical. ${ }^{3}$ Support for this hypothesis has been obtained from the demonstration that metabolic acidosis stimulates lipid peroxidation in brain homogenates and that addition of the iron chelator, deferoxamine prevents this acidosis-stimulated lipid peroxidation. ${ }^{4-6} \mathrm{~A}$ number of clinical studies have shown improved survival and physiologic function of postischemic rats and dogs given deferoxamine alone or in combination with other free radical "quenching" agents. ${ }^{7.10}$ Despite these clinical studies, the literature lacks histological data to support the proposed beneficial actions of deferoxamine in ischemia.

The objective of the present study was to assess whether deferoxamine or the superoxide dismutase mimic, manganese deferoxamine, have infarction-preventative activity in the rat.

\begin{abstract}
MeTHOdS
The experiments were performed on adult male Wistar rats (325-375 g) that were allowed free access to water and food. One day prior to hypoxemic-ischemic exposure the animals were anesthetized with i.p. pentobarbital $(50 \mathrm{mg} / \mathrm{kg})$ and the right carotid artery was surgically exposed and double ligated with 4-0 silk. The following day the animals were injected with $2 \mathrm{ml} \mathrm{25 \%}$ dextrose in water i.p. and $0.5 \mathrm{~h}$ later were placed in a plastic bell jar $\left(0.01 \mathrm{~m}^{3}\right)$ which was flushed with $1 \%$ carbon monoxide in air at a rate of $5 \mathrm{~L} / \mathrm{min}$. After $25 \mathrm{~min}$ exposure the animals were returned to room air. At 7 days post hypoxemiaischemia the animals were anesthetized with pentobarbital and the brain was fixed in situ by intra-cardiac perfusion of a brief $0.9 \%$ saline washout followed by $300-400 \mathrm{ml}$ of $10 \%$ formaldehyde. The fixed brain was subsequently prepared for paraffin sections, stained with cresyl violet and assessed for histological damage. The area of cerebral infarclion was measured using a video image processing program and measurements at 3 levels (approximately at 3,5 and $8 \mathrm{~mm}$ anterior to the interaural line) $)^{11}$ were averaged to give the value "area of infarction".
\end{abstract}

From the Division of Neurology, University of Toronto, Toronto (V.M.); and Departments of Biochemistry (I.F.) and Medicine (Neurology) (J.D.). Duke University, Durham, U.S.A.

Received March 18, 1992. Accepted in final form July 13, 1992

Reprint requests to: Dr. V. MacMillan, Room 6366, Medical Sciences Building, University of Toronto, Toronto, Ontario, Canada M5S 1A8 
The animals were divided into three treatment groups which were: (a) vehicle $-\mathrm{H}_{2} \mathrm{O}(\mathrm{n}=8)$; (b) deferoxamine $50 \mathrm{mg} / \mathrm{kg}(\mathrm{n}=$ 7); and (c) manganese deferoxamine $50 \mathrm{mg} / \mathrm{kg}(\mathrm{n}=7)$ which were given i.p. $0.5 \mathrm{~h}$ pre-exposure and at $0.5,3$ and $24 \mathrm{~h}$ postexposure. The results were analyzed using Wilcoxan's rank sum test for unpaired samples with $p<0.05$ being needed for statistical significance.

\section{RESUlTS}

Table 1 summarizes the survival data of the experimental groups. Two animals in the vehicle and one animal in the deferoxamine group died within minutes of the termination of hypoxemia-ischemia exposure and showed a picture of acute hemorrhagic pulmonary edema. One animal in each of the three experimental groups died on post-ischemia day 3-5 with a clinical picture of recurrent seizures and declining level of consciousness.

Table 2 gives the measured "area of infarction" for the three experimental groups. All 15 sections examined in the vehicle and deferoxamine groups showed infarction, with values for area infarcted ranging between $7.5-37.6$ and $4.4-41.1 \mathrm{~mm}^{2}$ for vehicle and deferoxamine groups, respectively. In the manganese deferoxamine group 15 of 18 sections examined showed infarction, with values for area infarcted ranging between 12.5 $42.8 \mathrm{~mm}^{2}$. The infarctions were predominantly located in the territory of the middle cerebral artery and showed involvement of grey, white and striatal structures (see Figure 1). The data indicates that pre- and post-treatment with deferoxamine and manganese deferoxamine had no significant attentuating effect on the development of or the size of infarction in this experimental model.

\section{Discussion}

The results of the present preliminary experiments provide no support for the suggestion that the iron chelator, deferoxamine may be of benefit in the prevention or treatment of cere-

Table 1: Survival of Rats Exposed to $1 \% \mathrm{CO}$ - Right Carotid Artery Occlusion and Iron Chelators

\begin{tabular}{lcccc}
\hline \hline $\begin{array}{c}\text { Experimental } \\
\text { Group }\end{array}$ & $\begin{array}{c}\text { Number } \\
\text { Exposed }\end{array}$ & $\begin{array}{c}\text { Number } \\
\text { Surviving }\end{array}$ & $\begin{array}{c}\text { Acute } \\
\text { Death }\end{array}$ & $\begin{array}{c}\text { Delayed } \\
\text { Death }\end{array}$ \\
\hline Vehicle $-\mathrm{H}_{2} \mathrm{O}$ & 8 & 5 & 2 & 1 \\
Deferoxamine & 7 & 5 & 1 & 1 \\
Mn-Deferoxamine & 7 & 6 & 0 & 1 \\
\hline
\end{tabular}

Table 2: Area of Infarction in Rats Exposed to $1 \% \mathrm{CO}$ - Right Carotid Artery Occlusion and Iron Chelators

\begin{tabular}{lcc}
\hline \hline $\begin{array}{c}\text { Experimental } \\
\text { Group }\end{array}$ & $\begin{array}{c}\text { Area of } \\
\text { Infarction } \mathbf{~ m m}^{\mathbf{2}}\end{array}$ & $\begin{array}{c}\text { \% of Brain } \\
\text { Section Infarcted }\end{array}$ \\
\hline Vehicle $-\mathrm{H}_{2} \mathrm{O}$ & $20.31 \pm 3.78$ & $28.5 \pm 5.0$ \\
Deferoxamine & $19.33 \pm 7.38$ & $31.7 \pm 12.1$ \\
Mn-Deferoxamine & $21.84 \pm 5.28$ & $30.6 \pm 6.8$ \\
\hline
\end{tabular}

Values are means $\pm S E M$ of 3 individual measurements done in each rat at $+3,+5$, and $+8 \mathrm{~mm}$ to the interaural line. bral infarction. ${ }^{1.28 .10}$ In addition, since the hyperglycemia hypoxemia-oligemia model used is associated with intense lactic acidosis, ${ }^{12}$ the results do not support the hypothesis that the tissue-damaging actions of acidosis may be expressed via the induced release of iron from tissue storage sites. ${ }^{3}$ The survival data also do not support previous reports that deferoxamine increases the survival rate after cerebral ischemia. ${ }^{7.9}$ Since these prior survival studies used a global ischemia model (i.e., cardiac arrest) the reported beneficial effects could well have been due to an action on systems other than the brain - i.e., heart,

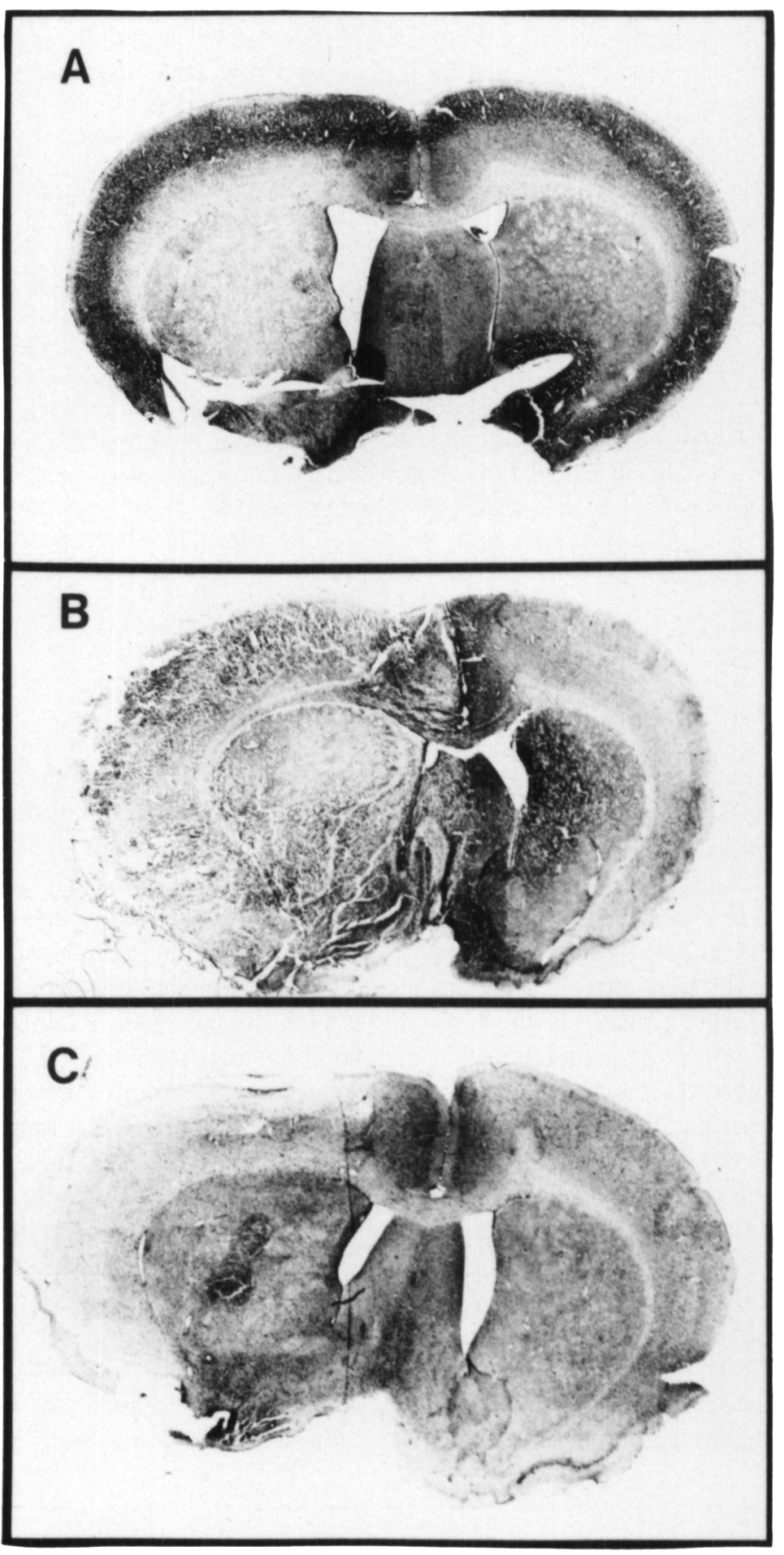

Figure 1 - Coronal sections of brains from rats exposed to carbon monoxide-oligemia and i.p. injections of $A$ ) vehicle $-\mathrm{H}_{2} \mathrm{O}, \mathrm{B}$ ) deferoxamine $50 \mathrm{mg} / \mathrm{kg}$ or C) $\mathrm{Mn}$-deferoxamine $50 \mathrm{mg} / \mathrm{kg}$. 
acid-base balance, etc. This conclusion is in agreement with the study of Fleischer et al. ${ }^{13}$ which showed no ability of deferoxamine to improve neurological outcome in dogs exposed to complete cerebral ischemia with intact coronary and pulmonary circulation.

The negative results of the present study are further reinforced by the fact that manganese-deferoxamine, a compound with 30 times the potency of deferoxamine, was also without beneficial effect. Previous reported studies have indicated improved survival of manganese-deferoxamine treated mice under conditions of hemorrhagic and endotoxic shock; ${ }^{14}$ a phenomenon which may have a similar mechanism to that proposed for the protective effect of deferoxamine in the cardiac arrest model.

The pathogenetic role of free radicals in ischemic brain damage has been difficult to establish. Thus, although numerous supportive in vitro studies are available, ${ }^{3}$ firm in vivo evidence of a prime role for free radicals in the causation of ischemic brain damage is generally lacking. In a recent review ${ }^{3}$ it was suggested that free radical damage would theoretically be important under circumstances of incomplete circulatory arrest (i.e., some $0_{2}$ to tissue) and acidosis (i.e., to delocate iron). Since both of these conditions are met in the present model of carbon monoxide intoxication and incomplete ischemia (i.e., tissue lactic acid levels of $30 \mathrm{mMol} / \mathrm{kg}$ in the hemisphere supplied by the clamped carotid artery ${ }^{12}$ ), the negative results of the present study offer no experimental support for this proposal.

The present model was patterned after the hypoxemiaischemia model of Salford et al.; ${ }^{16}$ and by the observation that addition of hyperglycemia leads to a high incidence of cerebral damage in this model. ${ }^{17}$ The experimental combination of carbon monoxide-carotid occlusion and hyperglycemia resulted in a 93\% incidence of cerebral infarction, with areas of infarction averaging about $30 \%$ of the total brain section. Although this high incidence of infarction made the present data easy to analyze, the small number of experimental animals suggests that extrapolation of the results to the clinical situation may require further study.

\section{ACKNOWLEDGEMENTS}

The preparation of this study was supported by the Ontario Heart and Stroke Foundation.

\section{REFERENCES}

1. White BC, Aust SD, Arfors KE, et al. Brain injury by ischemic anoxia: hypothesis extension - a tale of two ions? Ann Emerg Med 1984; 13: 862-867.

2. Babbs, CF. Role of iron ions in the genesis of reperfusion injury following successful cardiopulmonary resuscitation: preliminary data and a biochemical hypothesis. Ann Emerg Med 1985; 14: 777-783.

3. Siesjo BK, Agardh CD, Bengtsson F. Free radicals and brain damage. Cereb Brain Metab Rev 1989; 1: 165-211.

4. Aust SD, Svingen BA. The role of iron in enzymatic lipid peroxidation. Free Radicals Biol 1982; 5: 1-28.

5. Siesjo BK, Bendek G, Koide T, et al. Influence of acidosis on lipid peroxidation in brain tissues in vitro. J Cereb Blood Flow Metab 1985; 5: 253-258.

6. Rehncrona S, Hauge HN, Siesjo BK. Enhancement of iron-catalyzed free radical formation by acidosis in brain homogenates: difference in effect by lactic acid and $\mathrm{CO}_{2}$. J Cereb Blood Flow Metab 1989; 9: 65-70.

7. Kompala SD, Babbs CF, Blaho KE. Effect of deferoxamine on late deaths following CPR in rats. Ann Emerg Med 1986; 15: 405407.

8. Komara JS, Nayini NR, Bialick HA, et al. Brain iron delocalization and lipid peroxidation following cardiac arrest. Ann Emerg Med 1986; 15: 384-389.

9. Badylak SF, Babbs CFR. The effect of carbon dioxide, lidoflazine and deferoxamine upon long term survival following cardiorespiratory arrest in rats. Resuscitation 1986; 13: 165-173.

10. Cerchiari EL, Holl TM, Safar F, et al. Protective effects of combined superoxide dismutase and deferoxamine on recovery of cerebral blood flow and function after cardiac arrest in dogs. Stroke 1987; 18: 869-878.

11. Konig FR, Klippel RA. The Rat Brain: A Stereotaxic Atlas. Williams and Wilkins Company, Baltimore, 1963.

12. MacMillan V. Cerebral energy metabolism during recovery from carbon monoxide hypoxia-oligemia. Brain Res 1978; 151 : 353368.

13. Fleischer JE, Lanier WL, Milde JH, et al. Failure of deferoxamine, an iron chelator, to improve neurologic outcome following complete cerebral ischemia in dogs. Stroke 1987; 18: 124-127.

14. Garavilla L de, Chermak T, Valentine HL. et al. The superoxide dismutase (SOD) mimic manganese-deferoxamine (Mn-DFO) improves survival following hemorrhagic and endotoxic shock. FASEB J 1990; 4: A626.

15. MacMillan V. Cerebral carbohydrate metabolism during acute carbon monoxide intoxication. Brain Res 1977; 121:271-286.

16. Salford LG, Plum F, Siesjo BK. Graded hypoxemia-oligemia in rat brain: 1. Biochemical alterations and their implications. Arch Neurol (Chic) 1973; 29: 227-233.

17. Kalimo H, Rehncrona S, Soderfeldt B, et al. Brain lactic acidosis and ischemic cell damage: 2. Histopathology. J Cereb Blood Flow Metab 1981; 1: 313-327. 